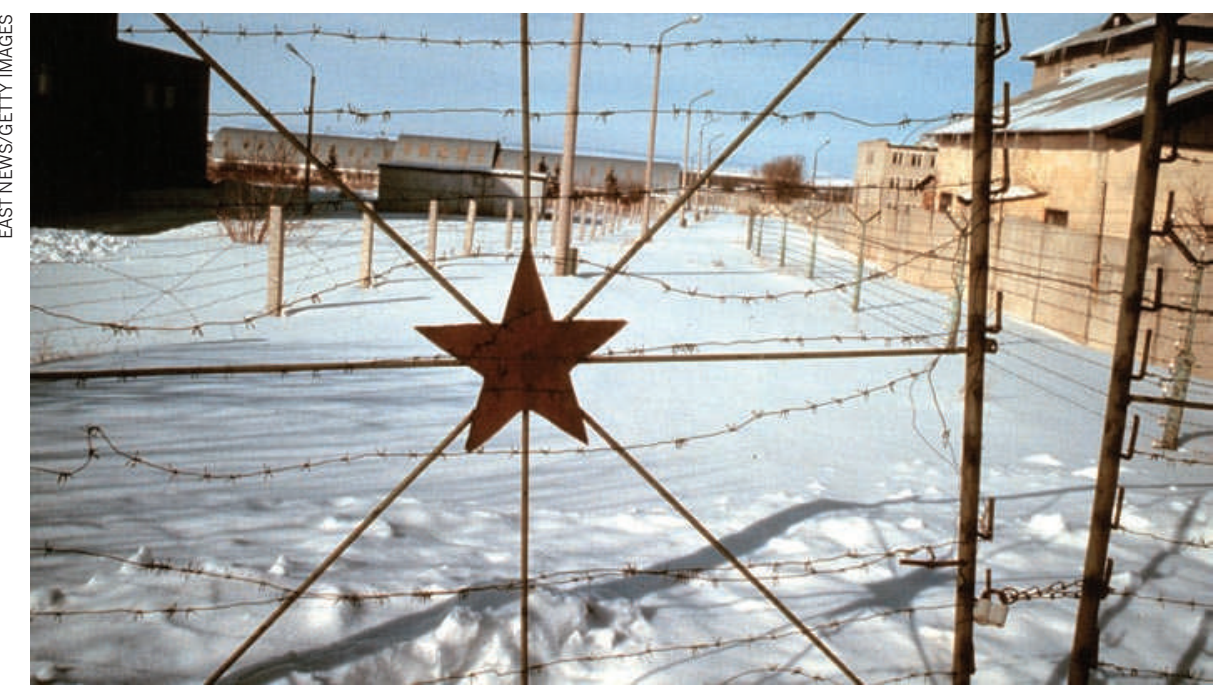

Former chemical-weapons scientists at Russia's Shikhany complex received Western support.

\title{
WEAPONS RESEARCH
}

\section{Curtain falls on collaborative work}

\section{End of the line for international funding agency that brought former Soviet weapons scientists in from the cold.}

\section{BY GEOFF BRUMFIEL}

A n international organization established to foster collaborations between Western researchers and weapons scientists of the former Soviet Union is set to close, Nature has learned. The Moscow-based International Science and Technology Center (ISTC) is now discussing its plans with the Russian government, which is increasingly irritated by the foreign handouts that the centre channels to the nation's weapons researchers. But some experts worry that the move - just months after President Dmitry Medvedev announced that Russia would withdraw its participation in the centre - will also sever a link between the country's weapons scientists and the rest of the world.

The centre was set up in 1992, just after the collapse of the Soviet Union. It was a dark time for thousands of scientists who had worked in the sprawling Soviet weapons complex, recalls James Toevs, an independent consultant and former US nuclear-weapons researcher based in Santa Fe, New Mexico. Shops were empty, and scientists went for months without pay. Toevs, who worked in Russia in the early 1990s, met nuclear-weapons designers who were forced to grow vegetables and do menial labour, such as repainting the local football stadium, to survive.
The United States, Japan, the European Union and the Russian Federation agreed to establish the ISTC to help alleviate the harsh conditions that scientists faced - and prevent weapons experts from taking their potentially dangerous knowledge elsewhere.

The centre organized international meetings

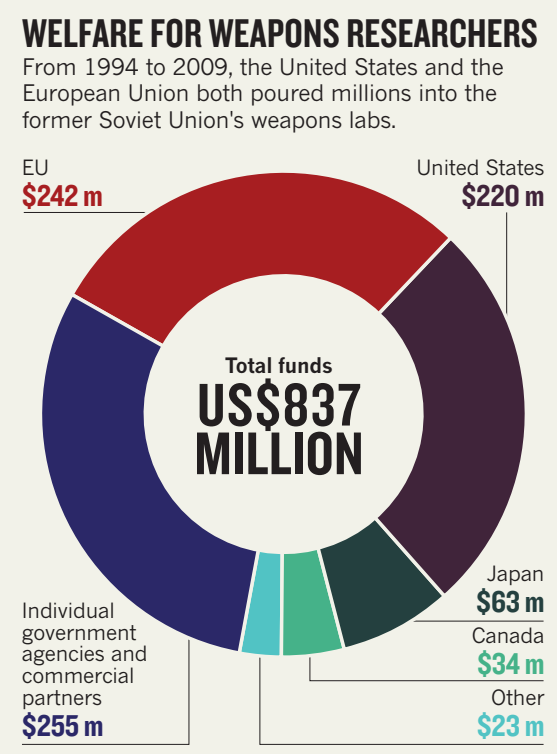

and disbursed generous grants to weapons designers who were willing to collaborate with counterparts in other countries. By the end of the 1990s, former Soviet satellite states were also benefiting - they, like Russia, did not have to pay into the scheme. From 1994 to 2009, the ISTC gathered more international partners and spent about US $\$ 837$ million on projects and meetings involving some 73,000 scientists (see 'Welfare for weapons researchers').

Not everyone was a fan of the programmes. "Some good science was done, but in the grand scheme of things it was ineffective," says Konstantin Severinov, a Russian-born virologist at Rutgers University in Piscataway, New Jersey, who worked on ISTC grants in Russia and in the former Soviet state of Georgia. Weapons scientists often performed low-quality research, and Severinov says that he saw cases in which extra scientists were added to projects unnecessarily to secure additional funding.

Adriaan van der Meer, ISTC executive director, concedes that in the early years, "we were probably more of a social programme than a research programme". But as time went on, the centre raised its scientific standards and even tried to help commercialize the work of researchers it supported. It also helped them find their way in the wider scientific world. "We got an opportunity to participate in international symposiums and to see how foreign scientists arranged their work," says Oleg Nagornov, a mathematician at the National Research Nuclear University in Moscow. Nagornov says that ISTC collaborations helped him to publish his first articles in Western journals, and he has maintained professional ties with some of the researchers he met.

As Russia's economy boomed in the past decade, the government began to reinvest in its weapons complex. It also became increasingly resentful of the centre's role as a foreign funder of research within its labs, according to multiple sources familiar with the organization. Russia's irritation led the European Union to stop funding new ISTC grants on Russian soil this year. Meanwhile, the United States has begun to shift its non-proliferation funding towards hot spots in Asia and the Middle East - regions where the threat seems more imminent.

The ISTC plans to shut down its programmes gradually over the next three or four years. But van de Meer hopes that it can be replaced with a new organization in which Russia is an equal partner. There is still a need for collaborative work on non-proliferation science, and a new generation of researchers must be engaged so that they're fully aware of the potential pitfalls of their dual-use knowledge, he says.

Andreas Persbo, the executive director of the Verification Research, Training and Information Centre, a London-based arms-control organization, agrees that a line of dialogue between Russian weapons scientists and the West is vital. He fears that "without the ISTC, that will gently decline". 